Published as: Grajales, Jacobo, J. 2020. From War to Wealth? Capitalist Peace and Land Policies in Côte d'Ivoire. Review of African Political Economy, 47(163), 78-94.

\title{
From War to Wealth? \\ Land Policies and the Peace Economy in Côte d'Ivoire
}

\author{
Jacobo Grajales
}

\begin{abstract}
This article studies the production of economic domination after the end of the Ivorian armed conflict. It investigates the interaction between post-conflict development policies, people's expectations and fears unleashed by the end of war, and the capacity of local actors to establish external alliances. The inquiry focuses on a region located at the margins of the conflict, but at the core of post-war development schemes. In this warless land, policies implemented in the name of peace provide resources for dominant actors seeking to consolidate their position, thus reinforcing the social structures of agrarian capitalism that had been challenged during the war.
\end{abstract}

\section{Résumé}

Cet article étudie la production de la domination économique après la fin du conflit armé ivoirien. Il analyse l'interaction entre les politiques de développement et sortie de conflit, les attentes et les craintes déclenchées par la fin de la guerre, et la capacité des acteurs locaux à établir des alliances externes. L'enquête se concentre sur une région située en marge du conflit, mais au cœur des programmes de développement post-conflit. Dans cette terre sans guerre, les politiques mises en œuvre au nom de la paix fournissent des ressources aux acteurs dominants qui cherchent à consolider leur position, renforçant ainsi les structures sociales du capitalisme agraire qui avaient été mises en cause pendant la guerre. 


\section{Introduction}

I first visited the village of Ayénouan, located in the Ivorian South-East, in early December 2016. Ayénouan is a place that encapsulates many of the contradictions of contemporary rural Côte d'Ivoire. The village is primarily populated by descendants of migrants and is marked by the long history of migration prompted by the colonial French state and by Felix Houphouët-Boigny's agricultural development policies. First encouraged by the colonial administration as a way of providing labour for the thriving cacao economy, migration patterns from the Northern to the Southern regions were reproduced by the newly independent state led by President Felix Houphouet-Boigny, who remained in power from the time the country gained its independence in 1960 until his death in 1993. This resulted in a social contract between autochthonous landholders, migrants, and the state, encouraged by bureaucratic despotism and patronage. The economic downturn of the 1980s led to the demise of this social contract and contributed to the political crisis and violence of the 1990s and 2000s (Chauveau 2000; Boone 2014).

Ayénouan is located at the heart of one of the fastest-growing regions of the country, where it is claimed that foreign and domestic investment have done away with political turmoil. A palm oil extraction mill run by Israel's Dekel Oil has operated in the immediate vicinity of the village since 2013. In the village school, a classroom wall proudly advertises, 'rehabilitated by Dekel Oil'.

The company's presence has not, however, been entirely uneventful. In January 2016, young people from the village blocked the access to the mill, before being dispersed by the police. Among various claims, they condemned the fact that the company had forcibly grabbed the land used to construct the mill and palm nursery ( 42 hectares). This had been done through the combined support of a rich planter and local state officials, both of whom took advantage of the climate of civil war (20022011) to deny migrants the right to claim rural land ownership.

Côte d'Ivoire, a case often considered by development practitioners as a peace-building success (for a critical view, see Akindès 2017), went through a nine-year armed crisis sparked by the attempted coup of September 2002 and characterised by the division of the country into two zones - a rebelcontrolled zone in the North and a government-controlled zone in the South - and a prolonged 'nopeace, no-war' situation punctuated by several outbreaks of violence (Dozon 2011; McGovern 2011; Viti 2014). In the southern zone, the war was often characterised by the stigmatisation of migrants, who were viewed as supportive of the rebels. The crisis came to an end in 2011 with the victory of the rebel forces, the appointment of President Alassane Ouattara, and the Frenchsupported extradition of former leader Laurent Gbagbo to The Hague. As Ouattara's main electoral base was in the north and among northern migrants in the south, he was generally viewed as supportive of their cause (Boone 2018).

Ayénouan, like the South-Comoé region as a whole, was far from the battle front. Yet this does not mean that war was inconsequential. Most descendants of migrants remember those years as times of arbitrary rule, when stigmatisation and dispossession were justified in the name of ethnicity. Consequently, the end of the armed struggle unleashed numerous expectations and fears; for migrants and descendants of migrants, Alassane Ouattara's victory held the promise of overturning 
the relations of domination previously in place. At the same time, autochthonous power holders who had generally supported Gbagbo - were seeking ways to counterbalance the uncertainties to their capacity to secure control over land.

In reality, for students of post-conflict economy formation, South-Comoé is home to a singular combination of characteristics. Though previous social hierarchies were not transformed by violence there, and dominant actors continue to occupy entrenched accumulation positions, it has been a preferred location for a number of post-conflict policies intended to support local land governance and boost agricultural production in the name of post-war capitalism. In short, it is a radical illustration of a phenomenon observed elsewhere: the way in which post-conflict policies strengthen the social structures of agrarian capitalism that were called into question during the war.

How can one make sense of this interaction between peace-building, corporations, and strategies of accumulation? Over the past decade, great efforts have been made to disentangle the mechanisms of post-conflict economy formation (Pugh, Cooper and Turner 2008; Jennings and Bøås 2015; Berdal and Zaum 2017; Distler, Stavrevska and Vogel 2018). Insightful examples of this research include West-African cases such as Sierra Leone (Millar 2015) and Liberia (Paczynska 2016).

While this literature has significantly refined our understanding of post-conflict accumulation, most of it deals with armed actors and government elites. Not only are they more visible, but their economic activities are considered as prime potential threats for peace (Le Billon 2008; Zaum and Cheng 2011; Cheng 2017; Torjesen 2017). As a result, much less is known about how small, local scale accumulation - often involving 'ordinary' people and everyday material competition - takes place. This is an important issue, because local processes of accumulation are crucial to the patterns of social transformation triggered by post-conflict policy-making (Mac Ginty and Richmond 2013). Moreover, accumulation on a local scale is quite a concrete phenomenon for people, as it involves neighbouring individuals and social groups; as such, it can be crucial to define what is seen as fair and unfair in terms of post-war social inequality. Ultimately, local processes of accumulation are embedded in larger processes of capitalist transformation (Aspinall 2009; Grajales 2020).

To avoid reifying the 'local', here local processes of accumulation are analysed as embedded and produced by a diversity of public policies which 'constitute moments of opportunity for local political players to assert (or reassert), to negotiate (or renegotiate), entrenched or more volatile positions in the fabric of local politics' (Lund 2008, 70; Lund 2016). Moreover, a number of possible contradictions arise from the fact that policy-making in the name of peace is a highly internationalised business, which claims to purport universal values and to create change in favour of the most vulnerable people (Mac Ginty 2016).

Consequently, in my case, I see post-conflict accumulation as shaped by three intertwined phenomena. First, it is fashioned by public policies that create new resources and spheres of power, enfranchising some people and disenfranchising others. Second, it is produced by the concurrent expectations and fears unleashed by the end of war: hopes of change or urges to consolidate previous dominant positions. Third, it is determined by the capacity of local actors to establish 'trans-local' alliances (Briquet and Sawicki 1989) and to use external resources in their localised power struggles. 
My point of departure will be the study of land policies. I will trace how they became critical peacebuilding and post-conflict development efforts. I will then move to the local level, analysing how struggles for accumulation and rights unfold. By the same token, I will show that competition for land can create new forms of exclusion, based not only on ethnicity, but also on gender.

Data for this paper was gathered during more than three months of research, undertaken during four different field research trips to Abidjan and South-Comoé between July 2016 and November 2018. I interviewed 95 informants across the following categories: peasants, Ivorian state officials at the local and national level, NGO staff, international development professionals in Abidjan and Paris and businessmen active in the palm oil industry. I was able to attend three village land committee meetings, where discussions took place in French or in Agni; in the latter case, I had the help of an interpreter. Finally, I also relied on the consultation of private archives and public registries in the Aboisso rural land office, alongside online public documents produced by Dekel Oil, the company active in the study region .

\section{Legal security, peace, and development}

In the aftermath of the Ivorian war, land was defined by international and domestic policy experts as a critical source of instability. However, while the government strived to portray the country as a stable, developing nation, land was also a vector of economic development. Most donors would support this claim, satisfied to participate in the transition from crisis to development and to redirect crisis aid elsewhere in the region.

The difficulties inherent in the dual pursuit of stabilisation and development were reduced, as often happens in the development industry (Li 2007), to a set of technical challenges. As such, ensuring legal security through the formalisation of customary land titles and guaranteeing the stability of land use and purchase contracts was proposed as the perfect solution, with the aim being both to pacify social relations in relation to land and provide the bedrock for business development. In the following pages, I will briefly analyse how a specific policy instrument - land formalisation - was labelled as a peace-building policy, before being reoriented towards development objectives and becoming a part of a broader reform of the private sector.

\section{Formalising land for peace}

Although land formalisation has a very long history in Côte d'Ivoire (Chauveau 2009), it underwent a reconfiguration when it was included in the country's post-conflict stabilisation and development agenda (Boone 2018, 206). During the war, government officials and aid practitioners depicted formalisation as one of the key responses to the crisis: reliable, legitimate, participative and transparent land tenure systems were supposed to contribute to a sort of 'bottom-up peace building'. Of course, this corresponded to international templates of conflict resolution (Unruh and Williams 2013). But the adoption of this approach must be traced back both to the work of humanitarian organisations in the field and to policy discussions in Abidjan. When international NGOs funded by foreign donors arrived in violence-ridden zones, they identified land as being at the core of the violence mechanisms. Tasked with 'conflict prevention', organisations such as the Norwegian Refugee Council (NRC) began to implement grassroots land management schemes (ABI 16.07.c; 
ABI 16.07.d). These practices are still prevalent today in western Côte d'Ivoire. At the same time, in Abidjan, rural land was becoming an important policy issue for foreign donors - especially the European Union. Land issues were a less sensitive topic than security-related issues. They provided a common field in which 'policy dialogue' could be maintained with the Gbagbo regime, in a context of harsh politicisation of foreign - especially French - influence in the country (ABI 17.03.22b; PAR 16.01.14).

In 2011, the end of the crisis gave newfound importance to existing land governance programmes. The end of armed conflict did not, in fact, put an end to the explosive social contradictions that had fuelled violence, especially in the countryside (Chauveau and Colin 2014; Toukpo 2015; Speight 2014). Beginning in 2011, most donors, even those who had initially been reluctant about the intervention on land issues - such as USAID - embraced the problem as part of an approach to violence prevention and peace-building. The solution for taking needed action was found in an existing statute from 1998 that was seldom applied: the Rural Land Act (Loi Relative au Domaine Foncier Rural, 1998). This was most assuredly not a law designed to promote social harmony. While this statute's history is complex and equivocal (Chauveau 2009), one of the law's aims was to exclude foreign residents from being able to legally purchase property (Boone 2018).

However controversial the bill was, it provided the only existing basis for the implementation of a formalisation policy. Post-conflict rhetoric was then mobilised to justify enforcing the law due to strong support from donors. While the World Bank official in charge of the issue remained very critical of the law's approach, considering it as legalistic and overly bureaucratic, the EU and the Agence Française de Développement (AFD) endorsed the Ivoirian government's commitment to enforcing the bill. This support was partly the consequence of the French government and the EU's desire to 'kick-start the Ivorian state machine' (ABI 17.03.22b; PAR 18.06.05). Formalisation held numerous advantages: it corresponded to the dominant liberal peace paradigm, which saw democracy and the enforcement of individual property rights as a magical remedy against violence; it corresponded to a regulatory framework that was friendly to foreign investment; and last but definitely not least, it echoed the Ivorian technocracy's beliefs regarding the neoliberal path to development.

\section{Property rights and economic development}

Nevertheless, in the years following the end of the crisis, the Rural Land Act progressively ceased to be approached from a perspective of peace-building. When I first came to Abidjan in the summer of 2016, most of the officials I spoke to at the ministry of agriculture and in the development assistance circles saw land formalisation as a development issue. According to them, distributing clear, robust rights to land would effectively revive both domestic and foreign investment potential. Today, the success of this development approach is exemplified by the creation of the Rural Land Agency in December 2016, which will be in charge of implementing a nationwide formalisation policy within the legal framework established by a slightly amendment 1998 law. While there has been strong civil society and donor pressure on the Ivorian government to adopt a more 'bottom-up' approach, combined with instruments of community governance and conflict management, the 
ministry of agriculture considers the new agency as basically a more flexible and effective way of distributing land titles (ABI 18.11.30a).

Non-judicial procedures aimed at pacifying land tenure relations do not fall within the agency's remit; though the government did not dismiss the goal of appeasing land tensions outright, it was simply no longer a task well suited to an organisation such as the Rural Land Agency. Instead, the issue could be handled either by other government programmes - such as the National Programme for Social Cohesion - or through the activities of foreign donors - such as the PBF (UN Peace Building Fund) conflict management programme.

The fact that Ivorian officials were concerned by the need to secure investment through formalisation reflected the ways in which the law has been applied to date. With the exception of those benefiting from massive land formalisation campaigns financed by foreign donors - most of which were still in their early stages at the time of my research - obtaining a property title is a long and expensive procedure. Applications for land certificates are filed with local rural land offices (Directions Départementales $d u$ Foncier Rural), which are in charge of conducting a neighbourhood inquiry. In addition, a cadastral record must be produced by a licensed land surveyor, who is a private contractor. Taxes and surveyor's fees - not to mention 'tips' for local officials - make it excessively expensive to obtain a land certificate. Moreover, until very recently, it was necessary to undertake additional procedures to transform the certificate into a title. The official price of such a process can be as high as 700,000 CFA francs (1,067 euros) for a fivehectare plot.

Consequently, the implementation of the Rural Land Act has been extremely slow and limited in scope. In the Aboisso department, where Ayénouan is located, only 571 land certificate requests had been submitted between 2009 and March 2017. A large number of these were unsuccessful, as only 118 certificates have been delivered. Among those who managed to obtain a certificate are engineers, doctors, civil servants and military personnel. Only six successful applicants declared themselves to be 'planters' (planteurs) or 'farmers' (agriculteurs). The vast majority of the home addresses provided by applicants were located in Abidjan. Six declared their residence to be in Europe or North America. This converges with literature arguing that formalisation policies risk facilitating the dispossession of the weakest claim-holders - the rural youth, women, and migrants - while favouring land concentration and therefore the process of accumulation by those who combine several forms of capital (Chauveau et al. 2006; Colin, Le Meur, and Léonard 2009; Musembi 2007).

\section{Legal security for corporations}

Legal security is not an issue solely for urban dwellers investing in the countryside, also referred to as 'Sunday farmers', or planteurs $d u$ dimanche. It is also instrumental in attracting and securing foreign investment. This objective is now seen as pivotal for the 'emergence' of the country on the international stage, in hopes of taking Côte d'Ivoire from war to wealth. However, creating a favourable environment for businesses is a complex aim, as the availability of land is hindered by a variety of tensions. 
Formalisation programmes provide an incomplete response to this problem, as one underlying justification for them is promoting peaceful and stable relations between local people and corporations. Yet businesses are not directly concerned by the procurement of title deeds, as property of rural land in Côte d'Ivoire is reserved for individuals with Ivorian citizenship. As such, the government has pursued alternative strategies for improving its capacity to make land available for safe investment. Former state concessions, many of which were abandoned in the 1980s and 1990s, are now being offered to agribusiness investors. This presents the advantage of a contract directly established between the state and the firm. This was the case in the department of Prikro (centre), where the government granted an 11,000-hectare concession to the CHC, a subsidiary of Belgium's SIAT, in 2011. The objections raised by locals were met with tremendous repression, with several marchers killed by police (GRAIN et al. 2017).

However, former state concessions are rare, and poorly maintained and lost records can render it difficult to identify them. Consequently, the most common approach has been to promote land deals between farmland investors and landowners. These deals can concern individual property owners, but they sometimes also involve village authorities. Lease agreements are signed directly by village chiefs as if they were property holders. The text of a lease signed between the village of Diby (described below) and an agribusiness corporation states that:

The corporation established a partnership with the village of Diby, landowner, represented by $\mathrm{Mr} \mathrm{X}$ [village chief] who agreed to lease several plots of land for the creation of industrial palm oil plantations, and will receive a third of the revenue (PrA 2011).

Agribusiness companies therefore conduct themselves as though village chiefs possess unlimited rights over land - rights that they do not necessarily hold in the eyes of the population. In fact, customary law in this particular region holds that chiefs are responsible for overseeing contracts and enforcing the law, but this confers no right of ownership over the land itself. Yet even if local authorities are aware of this, they recognise and enforce such contracts on the basis that chiefs are 'wardens of land' and that 'local governments have a duty to create a welcoming environment for investors' (ABO 17.03.16). This echoes the idea - defended by government officials - that these agreements bring 'development' to regions where people are unable to farm all the land they own:

Today, when investors want to invest, agreements are made with the people. In any case, there are farmers who have too much land and who cannot farm it. It is better if they make it available to an agribusiness company. In this way, the operator commits to making investments to and creating jobs (ABI 16.06.19).

The attempt to provide legal security to corporations and individuals gives rise to unintended effects. In the West, where most violence during the war was concentrated, formalisation has failed to stabilise the social relations around land and creates competition for titles to land between autochthonous dwellers and migrants (Chauveau and Colin 2014). In other regions of the country, which were spared by the war, autochthonous authorities use the notion of legal certainty to consolidate their position with regard to descendants of migrants. Both formalisation policies and agreements with agribusiness corporations provide avenues for this. 


\section{Competition for land}

Since the 1960s, South-Eastern Côte d'Ivoire, and South-Comoé in particular, has been a key zone for the development of export crops, chief among them palm oil, also because of public policies implemented through a state-owned company, Sodepalm. In 1997, the company was privatised and its assets in the South-East were purchased by a corporation named Palmci (Kouamé 2006). Along with oil palm, rubber trees have also been planted in abundance since the late 1990s, a period that corresponded to a global rubber boom, but also to an Ivorian land rush primarily featured by Gbagbo regime officials (Ruf 2013). Cacao, the Ivorian cash crop par excellence is also locally grown, even if an undetermined number of plots have been transformed into rubber tree plantations.

As elsewhere in Southern Côte d'Ivoire, South-Comoé is characterised by the ethnicisation of the political game, marked by competition between local Agni (belonging to the Akan group) - who refer to themselves as autochtones (sons of the soil) - and foreigners, whether Ivorian Northerners (seen as allogènes) or Burkinabè, Malian, and Guinean nationals - among others - (called allochtones) (Chauveau 2000; Boone 2014). Yet, contrary to other parts of the country, this polarised political game did not result in massive physical violence.

Being fairly stable, the region has been a preferred location for a variety of post-war development policies. The PARFACI programme for instance - an AFD funded effort to implement land certification schemes - chose the Aboisso department as one of its 15 locations for priority action. One of the motives for this choice was the exacerbation of land conflicts due to the presence of agribusiness investors (Direction du foncier rural 2014). Additionally, the economic recovery policy, which was intended to reinvigorate the country's agro-export potential, selected SouthComoe for the palm oil branch of PSAC, a 150-million-dollar programme funded by foreign donors. The programme's objectives were ambitious; in South-Comoé alone, the target was to increase the area dedicated to oil palm by 15,000 hectares. The reasons for this choice are easy to understand: even if the region did not require 'reconstruction', it boasted a favourable environment for policy implementation. It was far easier to support the economic development of an already prosperous territory than to endeavour to transform the troubled lands of the West into a new capitalist frontier. 


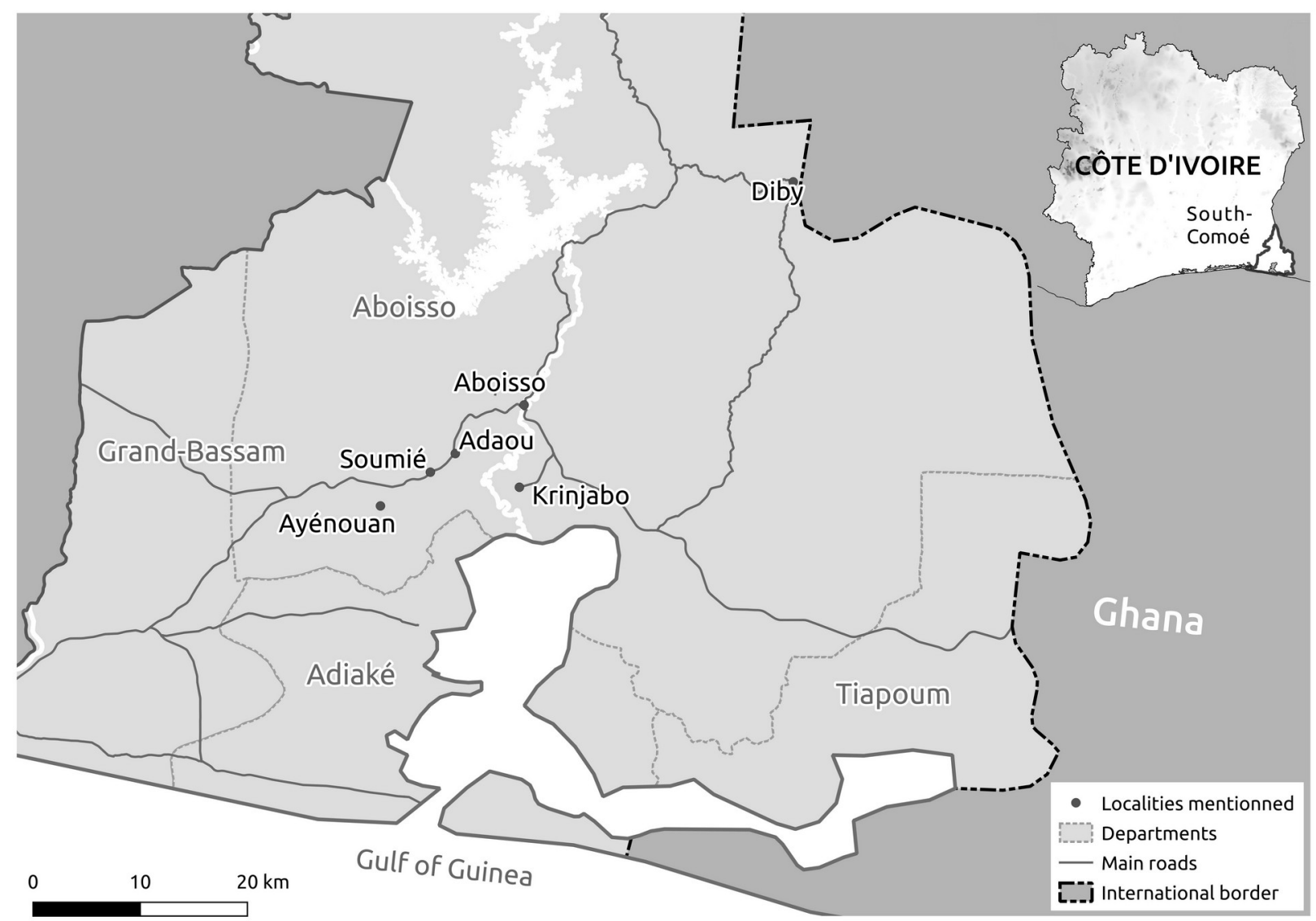

Source: the author, made with data from Naturalearthdata.com (public domain) and OpenStreetMap (Open Database License - ODbL)

\section{Formalisation and land governance}

Participation from 'local communities' is an important feature of the land formalisation procedure. Government officials and development practitioners view it as a sign of the democratic liberal stance of land governance and as a guarantee of effectiveness. Nevertheless, such participation is often restricted to neo-customary village authorities. Consultations are held within a 'village rural land governance committee', an organ often placed under the tight control of chiefs and the heads of powerful lineages. Reducing participation in consultations held by this body can, especially very heavily structured societies, lead to power being concentrated in the hands of neo-customary authorities and to those with less power being excluded - a sort of reshuffling of 'decentralised despotism' (Mamdani 1996).

This can be illustrated with the case of the village of Soumié, located not far from the regional capital of Aboisso. Soumié is a foreigner-populated locality placed under the authority of the neighbouring town of Adaou. Though the people of Soumié consider theirs as an independent village, the locality is officially a camp (campement). This means that the Soumié chief is not recognised by the local authorities, which considers Adaou neo-customary authorities as their only legitimate interlocutor. In practical terms, this means the Adaou chief has significant power over any transfer covering Soumié land. This is nothing new; in fact, it illustrates a generalised pattern of 
domination by autochthonous authorities over migrants elsewhere in Côte d'Ivoire (Boone 2018, 198). Moreover, the reassertion of autochthonous chieftaincies in the South-East has been observed since the 1990s (Soro 2009). This subordination worsened under the Gbagbo regime, which gave local authorities greater authority over migrants to consolidate its domination. Adaou elders benefited from that political context. They were well connected, and in 2008 they managed to upgrade their village to the administrative category of sous-prefecture, i.e. the headquarters of the deputy-prefect. Adaou's political influence was primarily used to establish control over land belonging to neighbouring villages.

Paradoxically, this situation of subordination has been aggravated by the implementation of the formalisation policy. The delimitation of villages - an important part of the process - offers neocustomary rulers an opportunity to strengthen their domination. This begins with the consultation of village land committees, which I was able to observe in December 2016. Being considered a camp, Soumié was not consulted. Instead, during the meeting with the Adaou committee, its president (a well-off planter and retired civil servant) and the village chief asserted that their territory covered Soumié and other neighbouring camps exclusively populated by migrants (Field notes, December 2016). No representative of these localities was ever consulted. When interviewed, the people of Soumié claimed they had not even been made aware of the existence of the delimitation process (field notes, March 2017). Of course, the use of formalisation as a tool for exclusion directed against migrants is not a novelty, and had already been observed during the 1990 rural land plan (Chauveau 2009, 127); what is new, however, is the existence of these trends in a set of circumstances that is supposedly far more favourable to the assertion of citizenship rights by those previously considered as 'foreigners'.

The Adaou chieftaincy also exerts pressure on behalf of powerful members of its community. The case that most affects the Soumié people concerns the son of a rich Adaou landowner and doctor, who claims to have inherited a 26-hectare plot from his father covering most of the territory of Soumié's populated centre. The Adaou chief asserts that this claim is legitimate and has granted the would-be landowner the right to treat Soumié villagers as squatters.

These trends of exclusion and potential dispossession are not merely a local matter. They correspond to a national policy shift in favour of neo-customary authorities, which is embedded in the post-conflict land tenure policy. During the armed crisis and in its immediate aftermath, SouthEast chiefs were seen as supportive towards Gbagbo (Perrot 2006). One of the strategies pursued by President Ouattara to gain the support of powerful constituencies in the South has been to strengthen the position of neo-customary authorities, who are particularly influential in the Akan territories. In line with this strategy, the new constitution created a consultative body called the Chamber of Kings and Traditional Chiefs. The real prerogatives of this institution are still blurred, but land governance is clearly at the core of their power.

\section{Agribusiness and village politics}

The appropriation of formalisation policies by dominant actors as a way of asserting power over land must be understood in the context of longer-term realignment of the social structures of agrarian capitalism. Indeed, combined with the strong interest in land from corporations, the result 
is the transformation of chieftaincies into economic brokers, a process already documented in neighbouring Ghana (Boamah 2014).

The Israeli company Dekel Oil settled in Côte d'Ivoire in 2007. In 2013, the firm completed the construction of a palm oil extraction mill in the town of Ayénouan, South-Comoé, and was granted a 13-year tax exemption from the government. In 2016, the company generated more than 26 million euros in revenue (Dekel Oil 2017). Dekel is a well-connected firm that benefited from the brokerage of influential players at a national level. Former Dekel Oil executive Daniel Boa claimed he was contacted in 2008 by the Israeli ambassador, who told him one of his compatriots was looking for a technical manager for his recently established palm oil firm (ABI 17.03.24). Dekel did not obtain a concession from the Ivorian state, but merely permission to negotiate access to land with local owners and neo-customary authorities. Nevertheless, this authorisation was ultimately granted, according to the land-specialised NGO GRAIN, thanks to the brokerage of a very well-connected person: Richard Kouassi Amon (GRAIN 2014). Amon is an heir to the royal family of Abengourou, a member of Felix Houphoët-Boigny's lineage, and CEO of an energy company.

If brokerage was important in garnering support for the company from national authorities, it was crucial when it came to local power arenas. In June 2008, one of Dekel's intermediaries, the Cooplato agricultural cooperative, was tasked with finding a suitable location for the extraction mill and the nursery. A zone of 42 hectares was identified in the village of Ayénouan. This was not vacant land; eight families possessed perennial trees (oil palm, rubber, and mangoes) on plots ranging from 2 to 16 hectares. Moreover, an area of approximately 19 hectares formerly owned by a French coffee grower was administered by the village chief and had been granted to a women's cooperative that grew cassava. However, Ayénouan has singular characteristics, which explain the fragile claim of its inhabitants over their own land; much like in the case of Soumié, the majority of the Ayénouan population is composed of migrants. As with Soumié, this puts Ayénouan under the domination of Adaou, though in a different way. Ayénouan is home to several thousand people and cannot be considered a simple camp. Its chieftaincy is formally recognised by the government and Adaou's institutions have weaker leverage than in the case of Soumié.

Still, Adaou elders consolidated their power over Ayénouan in the context of harsh politicisation of identity and property. In 1999, the death of the Ayénouan chief provided Adaou's authorities the opportunity to place a retired Agni civil servant at the head of the village. Strong opposition from Ayénouan's people ensued. This appointment went against the previous state of affairs, in which the village chiefs of Ayénouan had always come from migrant communities themselves. Nevertheless, the opposition was ultimately silenced with support from the government (Soro 2009).

Domination is not only based on institutional resources, but also on the social and economic capital of Adaou elites. One powerful member of the elite, Georges Bléhoué Aka, exemplifies this. He is one of Côte d'Ivoire's richest planters and was a close friend of Laurent Gbagbo. He was instrumental in the procurement negotiations for the mill estate. When Dekel and Cooplato showed interest in Ayénouan's site, negotiations took place between the firm, Adaou's chief, Ayénouan's newly nominated and unpopular chief, and Bléhoué Aka. A ninety-year lease was signed in 
October 2008 (PrA 2008), and a land certificate was established in the name of all three parties (PrA 2010).

Dispossession was made easier by the political crisis of the time. An Ayénouan villager remembers:

You know, at that time there was great hatred here for us Northerners. So everyone was scared. When the deputy-prefect said that we could not have land here because it was the land of the Agni, we were very afraid. That's why we had to give in to Dekel. (Ayénouan villager A, Ayénouan, December 2016)

As a matter of fact, their claims were dismissed by the government, which considered that Northerners - regardless of whether they were Ivorian citizens - lacked legitimacy to claim ownership over land:

We wrote a letter to the deputy-prefect. He told us - how dare you write a letter like that? A big company is coming to settle in South-Comoé, whether you like it or not. And we asked - what about the landowners? He answered - what landowners? Come and show me the land title! And he then told us - if you don't have a title, the land doesn't belong to you. You can't leave the North and own land here! (AYE 16.12.01b)

Consequently, the regime change was seen as an opportunity for social mobilisation. Ayénouan villagers harbour strong expectations regarding the possibilities of redress that could stem from the power shift in Abidjan. In 2016, six years after Ouattara's victory, calls for economic justice were expressed in these terms:

Today the debate has resurfaced because we know that we have the right, regardless of our origins, to have land here. Because article 28 of the constitution guarantees it [...] Now that the law is settled we will ask for a land certificate. We go to the land office and ask them to give us titles. (AYE 16.12.01a)

Ayénouan villagers have tried to mobilise different levers to obtain redress. The speaker quoted above is one of the leaders of the local anti-Dekel movement and an active member of the RDR (Rassemblement des Républicains - Ouattara's party) who has made an appeal to the district's legislator. This has proved fruitless. Contrary to his belief, the 2016 constitution did not change property rights in any way. The law never legally prevented Ivorian migrants from owning property, even if their claims were weakened in the political context of the time. Regarding foreign residents, the new constitution even strengthened the statutory provision from 1998 that prevented them from gaining access to ownership of rural land, a measure essentially meant to reassure Gbagbo supporters and Ouattara's own allies from the PDCI (the Parti démocratique de Côte d'Ivoire - former president Bédié's party). It reproduces the exclusion of descendants of migrants from accessing property, a measure that has not been fully offset by the country's naturalisation policy.

In reality, despite the shift in the partisan balance of power to the disadvantage of the almost exclusively Gbagboist local elite, this group's domination over village politics has been reproduced in the new political configuration. In 2013, during a meeting at the office of the prefect, the decision was taken to grant a title deed to Georges Bléhoué Aka (PrA 2013). This deed granted him full property rights over the 42-hectare plot that is now home to a mill designed to produce 70,000 
tonnes of palm oil each year. Ayénouan villagers have contested the title's validity in court, but their mobilisation has yet proved unsuccessful. Moreover, the legal domination of Adaou authorities over matters related to the governance of Ayénouan land, while contrary to the letter of the law, is recognised and enforced by local authorities. As such, the citizens of Ayénouan can nominate their own rural land committee, but the local administration will still treat its decisions as subordinated to the Adaou chieftaincy (ABO 16.12.07c; ADA 16.12.01).

\section{Identity, gender, and exclusion}

While categories such as 'autochthonous' and 'migrant' are necessary in order to untangle village politics, they do not do justice to these complex processes of exclusion. Migrants do not constitute a homogeneous group; they are divided by lines of class and gender. This final section elaborates on the interaction between identity and gender, analysing a case in which migrant women were dispossessed with the approval of both autochthonous and migrant men.

Sixty-five kilometres east of Ayénouan, in the village of Diby, a different form of dispossession was taking place during the same period. In 2010, the village chief signed a lease with Dekel covering 3,000 hectares of supposedly 'idle' land. Negotiations were undertaken by a cooperative of civil servants from the ministry of agriculture. Diby villagers today claim that this official pedigree inspired confidence. They also allege that Dekel intermediaries lured them into consenting by claiming that Diby might be an appropriate location for the mill. These were false promises, as Ayenouan's land had already been secured by then. Regardless, versions converge as to the enthusiasm elicited by the company's arrival.

Once the contract was signed, the following step was clearing the land. Through the intermediation of village authorities, groups of young men were formed. Their pay would depend on the amount of land they managed to clean. This is when conflicts arose. Oil palm was supposed to be planted on drained shallows, called bas-fonds, which is difficult to farm. Because of the low financial and symbolic value of this land, bas-fonds were essentially farmed by foreigners. Moreover, in light of the fact that humidity makes them unsuitable for cocoa and rubber, they were essentially devoted to food crops - which were generally produced by women. The occupants of the supposedly idle land' - which it was promised would make a fortune for the village - were therefore migrant women, a category of individuals with very weak claims to land:

In the shallows there was corn and rice. The foreigners farm them, because Agni people do not like to work in the shallows. It is normal that the land was taken from the foreigners, because it was not theirs; the elder had given it to them. (DIB 17.03.14)

Not only did the shallows suddenly begin to represent a valuable asset for local lineage chiefs and village authorities; granting leases to them was also a way of enforcing neo-customary authority over land in a context of significant politicisation of the issues of land and ethnicity. In the words of Diby's current village chief:

The transfer of these lands was a way for the customary authorities of the village to solve land issues, as foreigners had illegally occupied our land without giving anything back to the village in exchange. (KRI 16.12.02a) 
Backlash from the migrant community was organised by the foreign youth association. Groups of young men armed with machetes began to destroy the first planted palm trees. The politicisation of this conflict was linked to the general turmoil in the country. In the words of a former Dekel business partner:

In the beginning we worked quietly with the foreigners. And then Ouattara toppled Gbagbo. Then they felt strong! They started to ask for land and when they didn't get what they wanted they started to destroy plantations. (ABI 17.03.21b)

In reality, this migrant mobilisation corresponded to the final victory of the Forces Républicaines de Côte d'Ivoire (FRCI - the union of rebel groups that had fought against Gbagbo) a political context that emboldened the local foreign youth and frightened Agni authorities. With a FRCI division camped near the village, local foreign youth leaders tried - rather unsuccessfully - to further bolster their position by bringing the troops into the conflict. The tense situation resulted in the deployment of two armoured vehicles of Blue Helmets from the United Nations Mission to secure the village.

This polarisation brought about a crisis among village authorities, which motivated the intervention of the Sanwi king and the Maféré deputy-prefect. Some of the youths who had led the mobilisation took advantage of their newly acquired political capital to cut a deal with the company. Dekel's fees would be divided in eight equal shares: one for each of the seven Agni lineages and one for the foreigners. Their share of the money would be administered by the foreign youth association. The head of the association then became a fervent supporter of Dekel. In his own words:

In 2012, we found common ground and signed with the deputy-prefect. We'll give the shallows to Dekel and we'll all benefit. But some parents did not agree, they wanted to keep part of their land and continue farming. Then we convinced them to give up their land, because they did not have the means to work it. There was nothing in the shallows. You can't grow cocoa or rubber there. There was nothing but maize and rice. (DIB 16.12.09a)

The dispossession of the weakest category of the local population - foreign women - was thus legitimised by dominant actors of the migrant community. This exclusion was largely confirmed by the Agni chieftaincy, which managed to retain its dominion over land matters.

\section{Conclusions}

This article aimed to analyse post-war situations from the margins of war. As a matter of fact, South-Comoé is a relevant and paradoxical case for the study of post-conflict policy making. While the region was largely spared by armed conflict, it features a combination between the fears and expectations unleashed by the end of the war, the implementation of a certain array of public policies justified in the name of peace, and the reconfiguration of economic relations.

I retraced the development of a technical response to the political challenge of remodelling development while appeasing social and political tensions related to land. In this context, legal security was portrayed as the solution both for violence-ridden regions in the West and areas set to become agribusiness hubs, such as the South-East. However, village chiefs and other members of the local elite saw formalisation as an opportunity to consolidate their power at an uncertain 
conjuncture. In fact, they faced challenges both from below, given that previously oppressed migrant populations struggled to gain new rights ; and from above, as they needed to renegotiate their relationships with a government they had previously condemned. In this endeavour, neocustomary authorities were further able to use the arrival of agribusiness corporations for their own benefit. In this process, chiefs became capitalist brokers and gained further resources to consolidate their control over land.

The paper intervened in the debate on the political economy of peace-making by emphasising the interaction of public policies and business strategies with local processes of accumulation of capital. It offers a critique of post-conflict development thinking, which is based on the consideration 'that peace ushers forth an era of peace dividends' (Selby 2008, 24-5). This view is particularly well entrenched among post-conflict development practitioners and often guides the kind of international development interventions and national policy instruments that I discussed in this paper. Such a widespread influence makes it even more urgent to critically analyse the everyday reproduction of forms of capitalist accumulation and exploitation, concealed and rendered possible by the cloak of peace.

\section{References}

Akindès, Francis. 2017. ‘ «On ne mange pas les ponts et le goudron»: les sentiers sinueux d'une sortie de crise en Côte d'Ivoire'. Politique africaine, no. 148: 5-26.

Aspinall, Edward. 2009. 'Combatants to Contractors: The Political Economy of Peace in Aceh'. Indonesia, no. 87: 1-34.

Berdal, Mats and Dominik Zaum, eds. 2017. Political Economy of Statebuilding: Power after Peace. London: Routledge.

Boamah, Festus. 2014. 'How and Why Chiefs Formalise Land Use in Recent Times: The Politics of Land Dispossession through Biofuels Investments in Ghana'. Review of African Political Economy 41 (141): 406-23.

Boone, Catherine. 2014. Property and Political Order in Africa: Land Rights and the Structure of Politics. New York: Cambridge University Press.

Boone, Catherine. 2018. 'Shifting Visions of Property under Competing Political Regimes: Changing Uses of Côte d'Ivoire's 1998 Land Law'. Journal of Modern African Studies 56 (2): 189-216.

Briquet, Jean-Louis, and Frédéric Sawicki. 1989. 'L'analyse localisée du politique' [the local analysis of politics]. Politix 2 (7): 6-16.

Chauveau, Jean-Pierre. 2000. 'Question foncière et construction nationale en Côte d'Ivoire: Les enjeux silencieux d'un coup d'État' [Land issue and national contruction in Côte d'Ivoire : the silent stakes of a coup]. Politique africaine 78 (2): 94.

Chauveau, Jean-Pierre. 2009. 'La loi de 1998 sur le domaine rural dans l'histoire des politiques foncières en Côte d'Ivoire: la politique des transferts de droits entre "autochtones" et "étrangers" en zone forestière' [The 1998 Act on rural lands in the history of land policies in Côte d'Ivoire : the transfer policy between autochthonous populations and foreigners in the 
forest area]. In Les politiques d'enregistrement des droits fonciers: du cadre légal aux pratiques locales, 105-140, edited by Jean-Philippe Colin, Pierre-Yves Le Meur, and Eric Léonard. Paris: Karthala.

Chauveau, Jean-Pierre and Jean-Philippe Colin. 2014. 'La question foncière à l'épreuve de la reconstruction en Côte d'Ivoire' [The land issue confronted to the reconstruction of Côte d'Ivoire]. Les Cahiers Du Pôle Foncier, no. 6.

Chauveau, Jean-Pierre, Jean-Philippe Colin, Jean-Pierre Jacob, Philippe Lavigne-Delville, and Pierre-Yves Le Meur. 2006. Modes d'accès à la terre, marchés fonciers, gouvernance et politiques foncières en Afrique de l'Ouest [Modalities of land access, land markets, governance and land policies in West Africa]. Londres: IIED.

Cheng, Christine. 2017. 'Private and Public Interests: Informal Actors, Informal Influence, and Economic Order after War'. In Political Economy of Statebuilding: Power after Peace, 6377, edited by Mats Berdal and Dominik Zaum. London: Routledge.

Colin, Jean-Philippe, Pierre-Yves Le Meur, and Eric Léonard, eds. 2009. Les politiques d'enregistrement des droits fonciers: du cadre légal aux pratiques locales [Policies of land rights registration : from the legal framework to the local practices]. Paris: Karthala.

Dekel Oil. 2017. 'Final Results'. London Stock Exchange Regulatory News Service.

Direction du Foncier Rural. 2009. 'Étude d'impact social du volet d'appui à la mise en œuvre de la loi sur le foncier rural du PARFACI' [Social impact study for the implementation support of the Rural lands act, PARFACI programme].

Distler, Werner, Elena B. Stavrevska, and Birte Vogel. 2018. 'Economies of Peace: Economy Formation Processes and Outcomes in Conflict-Affected Societies'. Civil Wars 20 (2): 139-50.

Dozon, Jean-Pierre. 2011. Les clefs de la crise ivoirienne [The keys of the Ivorian crisis]. Paris: Karthala.

GRAIN. 2014. 'Feeding the 1 Percent. An IT Billionaire's Foray into Agribusiness Paints a Disturbing Picture of Today's Farmland Financiers'.

GRAIN, IDEF, Eburnie today, and JVE. 2017. 'Conflit foncier en Côte d'Ivoire: les communautés se défendent face à SIAT et l'État' [A land conflict in Côte d'Ivoire : communities defending against SIAT and the state].

Grajales, Jacobo. 2020. 'Losing land in times of peace: post-war agrarian capitalism in Colombia and Côte d'Ivoire'. Journal of Peasant Studies. DOI: 10.1080/03066150.2019.1691535

Jennings, Kathleen M., and Morten Bøås. 2015. 'Transactions and Interactions: Everyday Life in the Peacekeeping Economy'. Journal of Intervention and Statebuilding 9 (3): 281-95.

Kouamé, Yao Séverin. 2006. 'Privatisation et stratégies de résilience dans les eExploitations villageoises de palmier à huile en bBasse Côte d'Ivoire' [Privatisation and strategies of resilience in the peasant plantations of palm oil in Lower Côte d'Ivoire]. PhD diss., Bouaké: Alassane Ouattara University.

Le Billon, Philippe. 2008. 'Corrupting Peace? Peacebuilding and Post-Conflict Corruption'. International Peacekeeping 15 (3): 344-61.

Li, Tania Murray. 2007. The Will to Improve: Governmentality, Development, and the Practice of Politics. Durham: Duke University Press.

Lund, Christian. 2008. Local Politics and the Dynamics of Property in Africa. Cambridge University Press. 
Lund, Christian. 2016. 'Rule and Rupture: State Formation through the Production of Property and Citizenship'. Development and Change 47 (6): 1199-1228.

Mamdani, Mahmood. 1996. Citizen and Subject: Contemporary Africa and the Legacy of Late Colonialism. Princeton University Press.

McGovern, Mike. 2011. Making War in Cote D'Ivoire. London: Hurst

Mac Ginty, Roger. 2016. International Peacebuilding and Local Resistance: Hybrid Forms of Peace. Palgrave Macmillan.

Mac Ginty, Roger, and Oliver P. Richmond. 2013. 'The Local Turn in Peace Building: A Critical Agenda for Peace'. Third World Quarterly 34 (5): 763-83.

Millar, Gearoid. 2015. 'Investing in Peace: Foreign Direct Investment as Economic Restoration in Sierra Leone?' Third World Quarterly 36 (9): 1700-1716.

Musembi, Celestine Nyamu. 2007. 'De Soto and Land Relations in Rural Africa: Breathing Life into Dead Theories about Property Rights'. Third World Quarterly 28 (8): 1457-78.

Paczynska, Agnieszka. 2016. 'Liberia Rising? Foreign Direct Investment, Persistent Inequalities and Political Tensions'. Peacebuilding 4 (3): 297-316.

Perrot, Claude-Hélène. 2006. 'Chefs traditionnels : le cas du sud-est de la Côte d'Ivoire' [Traditional chiefs : the case of South-Eastern Côte d'Ivoire]. Afrique contemporaine, no. 217 (June): $173-84$.

Pugh, Michael C., Neil Cooper, and Mandy Turner. 2008. 'Introduction'. In Whose Peace?: Critical Perspectives on the Political Economy of Peacebuilding, 1-11. Basingstoke England; New York: Palgrave Macmillan.

Ruf, François. 2013. 'Agriculture contractuelle et boom de l'hévéaculture villageoise cn Côte d'Ivoire' [Contract agriculture and the boom of rubber farming in Côte d'Ivoire]. Cahiers Agricultures 22 (1): 46-52.

Selby, Jan. 2008. 'The Political Economy of Peace Processes'. In Whose Peace?: Critical Perspectives on the Political Economy of Peacebuilding, 13-31, edited by Michael Pugh, Neil Cooper and Mandy Turner. Basingstoke England; New York: Palgrave Macmillan.

Soro, Marcelline. 2009. 'Dynamiques des systèmes de production, droits fFonciers et gestion intrafamiliale de la terre chez les migrants Sénoufo dans le Sanwi' [Production system dynamics, land rights and land intra-family management schemes among the Senoufo migrants of the Sanwi]. PhD diss., Abidjan: Université Félix-Houphouët-Boigny.

Speight, Jeremy. 2014. 'Warlord Undone? Strongman Politics and Post-Conflict State-Building in Northeastern Côte d'Ivoire (2002-2013)'. Canadian Journal of African Studies 48 (2): 223 41 .

Torjesen, Stina. 2017. 'Transition from War to Peace: Stratification, Inequality and Post-War Economic Reconstruction'. In Political Economy of Statebuilding: Power after Peace, 4861, edited by Mats Berdal and Dominik Zaum. London: Routledge.

Toukpo, Oscar. 2015. "Stratégies de repositionnement et jeux fonciers d'acteurs en contexte postconflit dans les départements de Blolequin et Toulepleu" [Strategies for Land Access and Repositioning in a Post-conflict Context in the Departments of Blolequin and Toulepleu]. PhD diss., Abidjan: Université Félix-Houphouët-Boigny.

Unruh, Jon, and Rhodri Williams. 2013. Land and Post-Conflict Peacebuilding. London: Routledge. 
Viti, Fabio, ed. 2014. La Côte d'Ivoire, d'une crise à l'autre [Côte d'Ivoire, from one crisis to the next]. Paris: L'Harmattan.

Zaum, Dominik, and Christine Cheng, eds. 2011. Corruption and Peacebuilding: Selling the Peace?. London; New York: Routledge.

\section{Primary sources}

Only sources referenced in the text are listed below

ABI 16.07.c : Interview, EU rural development official, Abidjan, July 2016

ABI 16.07.d : Interview, AFD rural development official, Abidjan, July 2016

ABI 16.07.19 : Interview, Deputy director, Production division, Ministry of Agriculture, Abidjan, July 2016

ABI 17.03.22b : Interview, EU rural development official, Abidjan, March 2017

ABI 17.03.21b : Interview, Former cooperative manager, Abidjan, March 2017

ABI 17.03.24 : Interview, Former Dekel executive Daniel Boa, March 2017

ABI 18.11.30a: Interview, Director, Rural lands division, Ministry of agriculture, Abidjan, November 2018

ABO 16.12.07c : Interview, Rural land office surveyor, Aboisso, December 2016

ABO 17.03.16 : Interview, Prefect chief of staff, Aboisso, March 2017

ADA 16.12.01 : Interview, Deputy prefect, Adaou, December 2016

AYE 16.12.01a : Interview, Ayénouan villager, December 2016

AYE 16.12.01a : Interview, Ayénouan villager, December 2016

DIB 16.12.09a : President of the foreign youth association, Diby, December 2016

DIB 17.03.14 : Interview, Young villager, member of an Agni family, Diby, March 2017

KRI 16.12.02a : Chief of Diby, Krinjabo, December 2016

Loi relative au domaine foncier rural [Rural lands act], n98-750, 23 December 1998, available from http://www.fao.org/faolex/results/details/en/c/LEX-FAOC015631

PAR 16.01.14 : Field notes, AFD meeting, Paris, January 2016

PAR 18.06.05 : Interview, French foreign ministry official, Paris, June 2018

PrA 2008 : Private archives, Contrat de bail emphytéotique entre les propriétaires (Bléhoué Aka Géorges, Ahoni Bénié et Tanoh Kablan) et le preneur (Dekel Oil) [Leasing agreement between the owners and the tenant]. 15 October 2008.

PrA 2010 : Private archives, Certificat foncier collectif [collective land certificate] n57-2010000001. Ministère de l'Agriculture. Département d'Aboisso. 10 May 2010. 
PrA 2011 : Private archives, Convention de partenariat avec le village de Diby [Partnership convention with the village of Diby]. 5 January 2011.

PrA 2013 : Private archives, Procès verbal de la réunion du 26 avril 2013 [Minutes of the meeting]. Préfecture d'Aboisso. 26 April 2013.

\section{Acknowledgements}

I am particularly grateful to Jean-Pierre Chauveau, who read and generously commented the first version of this paper. In Lille, Abidjan, Diby and Ayénouan I have enjoyed the help and friendship of Marie Saiget, Oscar Toukpo, Gabin Tarrouth, Arsène Gnanin and Kalilou Kamara. A previous version of this paper was presented in the 'Doing Public Policies in Africa' seminar, at Sciences Po Bordeaux and benefited from insightful comments from the public and participants. I finally wish to thank anonymous reviewers and RoAPE editors for their very rigorous but considerate evaluation.

\section{The author}

Jacobo Grajales is professor of political science at the University of Lille, France, and fellow of the Institut Universitaire de France. Having previously conducted research on the relationships between the state and armed groups in Colombia, he is now examining the links between post-conflict politics and land policies, with a comparative perspective. His past and current research projects and publications can be retrieved at www.jacobo-grajales.net.

Email: jacobo.grajales-lopez@univ-lille.fr

\section{Funding}

Funding for this research was provided by the Agence Nationale de la Recherche (ANR) under the contract ANR-17-CE41-0001, as well as by the Fondation de la Maison des Sciences de l'Homme, within the 'Nouvelles conflictualités' research programme. 